\title{
1 \\ Introducing Paul Dibb (1): Britain's Loss, Australia's Gain
}

\author{
Allan Hawke
}

Emeritus Professor Paul Dibb AM is notoriously protective of his private life, so this introductory note tries to give some insight into the man behind the legend without trespassing too far into his privacy.

In a reflection on his own life as an intellectual, Des Ball quoted Karl Mannheim's explanation that it is difficult for intellectuals to separate their work and domestic domains. In a veiled reference to the price that is sometimes exacted in personal relationships, Des went on to say that thinking doesn't stop at home in the evenings or on weekends. ${ }^{1}$

Paul was appointed a Member of the Order of Australia (AM) on Australia Day 1989 for 'public service'. He has made a sustained, significant and enduring contribution to defence, intelligence and national security for over 30 years.

The articles that follow showcase this claim, although much of his work in the intelligence area is necessarily not in the public arena. They provide a glimpse of his intellect, analytical skills, lectures and writing in all these fields.

1 Desmond Ball, 'Reflections of a Defence Intellectual', in Brij V. Lal \& Alison Ley (eds), The Coombs: A House of Memories, 2nd edn (Canberra: ANU Press, 2014), p. 149. 
When I was a teenager, my father (who Paul knew when they were in the Department of Trade) took me out to the laundry, filled a bucket with water, put my arm in it up to the elbow and then removed it. He said, 'Son, that's the mark that most men leave on the world'. Not so with Paul. One measure of the worth and legacy that Paul will leave can be found in the calibre of the authors in this testimonial - a veritable galaxy of people whose life work has been devoted to serving Australia's defence and national interests.

I first met Paul in 1985 when the Defence Secretary, Sir William Cole, asked me to make the necessary arrangements for the Review of Australia's Defence Capabilities, better known as the Dibb Review. ${ }^{2}$

We have been colleagues, collaborators and mates ever since - even after my remarks at his 60th birthday at the Burrawang pub - and we have shared dinners and visits in Canberra and at his Robertson farm together with Paul's spouse Rhondda Nicholas.

Defence Minister Kim Beazley described Paul's work as '... the most important appraisal of Australia's Defence capabilities since the end of World War Two'. The 1987 White Paper, The Defence of Australia, written largely by Paul, set the standard for those that have followed. The conceptual architecture of the self-reliant Defence of Australia (DOA) doctrine, which Paul developed then, still stands Australia in good stead and should remain the basis for future capability reviews and force-structure decisions.

Fast forward to 1991 when I was transitioning from Deputy Director of the Defence Signals Directorate to succeed Paul as Deputy Secretary (Strategy and Intelligence) in Defence. I had the great fortune to be the 'roadie' on Paul's farewell world tour before he left Defence in July 1991 to become head of The Australian National University's (ANU) Strategic and Defence Studies Centre (SDSC).

The legendary Sir Arthur Tange said in support of Paul's appointment that he had 'rare versatility' and 'there is none inside or outside the Defence community better equipped at present to understand the issues in contention and the policy choices'. Rare praise indeed from the Great Mandarin.

2 Paul Dibb, Review of Australia's Defence Capabilities, report to the Minister for Defence (Canberra: Australian Government Publishing Service, 1986). 
After doing the rounds of the Washington agencies and departments, where Paul inter alia reprised his work and influence on US officials about the Soviet Union, we flew into Manchester airport on a Friday evening with three day's grace before a set of appointments in London.

We based ourselves in York from where, as fellow members of the High Church of England, we attended the evening service at York Minster seated in the bishop's row of chairs. We also undertook a pilgrimage to Beverley to call on Paul's Uncle Jack and Aunty Paula. Jack, who was on his last legs suffering from emphysema, got out of bed, took off his oxygen mask and came to the lounge room where he promptly lit a cigarette while sharing a large glass of whisky with us. There were tears all round when we departed for dinner at Paul's mother's house.

While in York, we took a side trip to have a look at the UK-US intelligence base at Menwith Hill. We got lost when going there and pulled in to a housing estate to seek directions from an old lady who was walking along the street. 'Oh you mean spy base', she said in a broad Yorkshire accent and pointed the way. Almost as soon as we arrived and drove around the outskirts, we were pulled over by the police, questioned about why we were there and asked to show our passports (which we didn't have with us).

On arriving in London to see the head of UK Government Communications Headquarters, Sir John Adye, we found that our visit had already been reported to him, leading to some friendly banter about the different arrangements with the United States between the UK and Australian joint facilities.

A further call on Sir Malcolm McIntosh, the Australian-born head of the UK Procurement Office, led to an exchange where Malcolm in his broadest Australian accent said, 'On behalf of her Majesty's United Kingdom Government, I have to tell you ...' Paul, reverting to his Yorkshire accent, replied, 'Well, I'm authorised to tell you that the Australian Government ...'.

Paul, an only child, was born on 3 October 1939. His mother Ethel who was 'in service' as a maid to a local solicitor was evacuated from Hull where they lived during the war - to live with her sister while awaiting Paul's arrival. We paid homage by visiting 4 William Street in Fryston, the coalmining village where Paul was born. 
Ethel's marriage to Paul's father, Cyril - a trolley-bus driver who died in the early 1970s - didn't last and she remarried Alec Harbottle who was a Merchant Navy captain during the Second World War. After the war, Alec resumed his occupation as a coalminer, becoming a pit bottom deputy. When Paul was 17, Alec took him down the pit, following which, the experience having the desired effect, coalmining was taken off Paul's list of possible careers.

After Tanshelf primary school at Pontefract, Paul sat an examination known as the Eleven Plus that, together with an IQ test, determined whether one could go on to high school. If you did not succeed on those tests, your fate was to be a coalminer, bus driver or tradesman. Paul passed and went on to the state grammar Kings School at Pontefract.

From Kings School, Paul won a County Exhibition Scholarship to undertake a Bachelor of Arts in economics and geography with honours, graduating from Nottingham University in 1960. Following university, Paul became an apprentice manager at a Midland's chrome component factory for motor vehicles, which may well have been where he got his taste for fast cars!

The Careers and Appointments Board of Nottingham University had advised Paul that, as he had not been to Eton or Harrow, Cambridge or Oxford, any application of his for the civil service would not succeed. Paul went ahead and applied to become an administrative graduate trainee only to receive a rejection letter saying that he shouldn't bother to apply again in the future. Britain's loss was to turn out to be Australia's gain.

The son of the owner of an Australian company that was bought by Paul's employer was sent to the England to learn the ropes. Over a few sherbets one evening, he took Paul aside and asked why he was wasting his time working in the factory when he could come to Melbourne. Paul's response was that Australia was on the other side of the world and it was all desert.

At this point, serendipity played its role in Paul's future in the form him noticing an advertisement in a national newspaper calling for British subjects to join the Australian Commonwealth Public Service and offering a salary 50 per cent higher than Paul was being paid. He landed a job with the Department of Trade and, in return for a three-year bond, the Dibb family's relocation was paid for by the Australian Government. 
Mr P. Dibb BA with Mrs Dibb and child left Tilbury Docks on 30 November 1961, a dreary, grey and foggy winter day, travelling first class on the SS Orcades with one suitcase and little money. Side trips to Gibraltar, Naples and Pompeii followed before transiting the Suez Canal, Aden and Colombo, arriving in Fremantle at the start of a blazing hot summer where the family were surprised to see local urchins running around in bare feet and shorts.

Paul can still remember his first encounter with the aroma of meltinghot road tar on the street outside the Adelaide railway station as they were on their way to Sydney, six weeks after their departure from England.

The family moved to Canberra to begin their new life in Hovell Street, Griffith, and in January 1962 Paul started as a Research Officer Grade 1 on the UK desk of the Department of Trade at a time when the imperial ties between Australia and the mother country were unravelling as Britain joined the Common Market. Paul worked with a number of Australian luminaries, including Max Moore-Wilton, during the period from 1962 to 1967.

In 1965, Paul joined Stuart Harris, the senior economist at the Bureau of Agricultural Economics (BAE), as a Class 8 to write a paper on the economics of the Soviet wheat industry. Coincidentally, I was also at the BAE at this time from November 1965 to March 1966, when I began my undergraduate degree at ANU. Paul's paper was published in 1966, ${ }^{3}$ leading the US Department of Agriculture to observe that it was the best paper ever on the subject. This period continued Paul's long-term interest in the Soviet Union, which had been piqued during his university studies.

After a short stint in 1967 as a Class 9 working directly for George Warwick Smith, the Secretary of the Territories Department, on the independence negotiations for Nauru, Paul was enticed to ANU in 1968 to be a research fellow in the Research School of Social Sciences (RSSS) and to work with Harry Rigby, one of the top ten Soviet specialists in the world at that time. That led to Paul's book, Siberia and the Pacific: A Study in Economic Development and Trade Prospects.

3 Paul Dibb, The Economics of the Soviet Wheat Industry: An Economic Study of the Structure, Trends and Problems from 1953 to 1965 with a Perspective to 1970 (Canberra: Bureau of Agricultural Economics, 1966). 
From there, Paul went to work for Bob Furlonger in the Joint Intelligence Organisation (JIO) in Defence in 1970 in the Directorate of Economic Intelligence. In 1972, Paul moved to the National Assessments Staff (NAS) (the forerunner of Office of National Assessments (ONA)), becoming head of that office in 1974. Then, in 1980, Bill Pritchett, secretary of Defence, appointed Paul as senior assistant secretary of Strategic Policy.

In 1981, Bob O'Neill poached Paul back to ANU to write The Soviet Union: The Incomplete Superpower, for which he was awarded a $\mathrm{PhD}$ in 1988. ${ }^{4}$ The first edition of the book on this subject was published in 1986, followed by a second edition in 1988 .

Paul's status as Emeritus Professor of Strategic Studies at ANU is a fitting tribute to the continuing pre-eminence of his work. His Russian expertise is again at the fore, given recent developments in Russia and Vladimir Putin's ambitions, while his considered views on the rise of China are also increasingly important.

Indeed, another measure of the man lies in the nine years that he has spent as Australia's representative on the Association of Southeast Asian Nations (ASEAN) regional forum Experts and Eminent Persons Group, which he now co-chairs with Singapore.

It's no accident that ministers and parliamentarians of different political persuasions, ministerial staff, senior officials and think tanks (at home and abroad) have sought Paul's counsel (and continue to do so) on defence, foreign affairs and national security matters.

It's a particular privilege that I know Paul's adult children (a daughter and a son), and he has two grandsons, one of whom shares his passion for high performance cars in his work for the Red Bull Formula One racing team.

I'm proud to be a mate and very much appreciate the opportunity to provide this context on a modern-day giant - $\mathrm{a}$, if not the, doyen of his field.

Current and future scholars who aspire to that honorific would do well to study and digest the lessons herein.

4 Paul Dibb, The Soviet Union: The Incomplete Superpower (London: International Institute for Strategic Studies and Macmillan, 1986). 
This text is taken from Geography, Power, Strategy and Defence Policy: Essays in Honour of Paul Dibb, edited by Desmond Ball and Sheryn Lee, published 2016 by ANU Press, The Australian National University,

Canberra, Australia. 